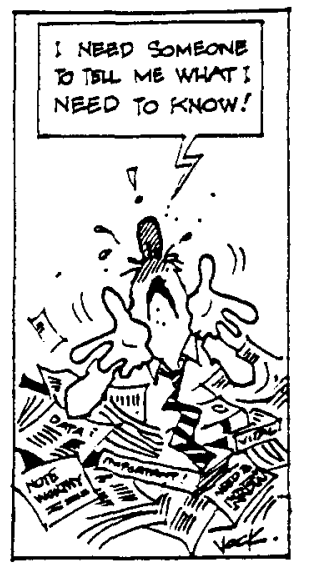

Organisations

Includes:

- NEXUS, issued monthly ( 2 copies if required)

Additional copies of NEXUS, either to the same or another location, are available for an additional charge - please contact Information Seroice staff for details.

Individuals . . . . . . . . . . . . . . . . . . . \$ \$140

(personal cheque \& home address required)

Includes: - NEXUS, issued monthly $\quad 5$ photocopied articles

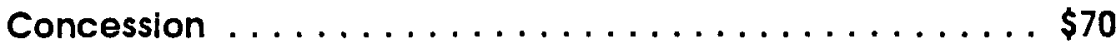

(students \& individuals not in paid employment)

Includes: $\downarrow$ NEXUS, issued monthly 5 photocopied articles

Nexus only ........................

Additional services available at non-subscriber rate

Nexscan . . . . . . . . . . . , \$100 (12 months), $\$ 50$ (6 months) , $\$ 20$ (1 month) Includes: - Searches of the Information Service database on request (either personal visit or phone)

- optional automatic monthly update of registered search to cover items added to the collection

- access to all additional services at subscriber rate (restrictions apply to 1 month subscriptions)

\title{
Additional Services
}

- Photocopled articles

\section{- Book borrowing}

4 week loan period. Limit of 6 concurrent loans.

- Book borrowing subscription

For subscribers wishing to borrow books on a regular basis. Unlimited book borrowing over subscription period (same conaltions apply as above). Nominal charges to interstate borrowers to cover additional postage costs.

- Video borrowing

2 week loan perlod. Limit of 2 concurrent loans.

Replacement cost charged for loss/damage.

- Video borrowing subscription

For subscribers wishing to borrow videos on a regular basis. Unlimited borrowing over subscription period (same conditions apply as above).

- Database searches
Information Service subscribers

$\$ 3$ per article

$\$ 3$ per book

plus postage

$\$ 50: 6$ months

$\$ 100: 12$ months

$\$ 10$ per video

plus postage

$\$ 20$ per video plus postage

$\$ 50: 6$ months $\$ 100: 12$ months

not arailable
Non-subscribers Nexus only

$\$ 6$ per article

$\$ 9$ per book plus postage

not available

$\begin{array}{rll}<10 \text { minutes } & \text { no charge } & \$ 10 \\ 10-30 \text { minutes } & \$ 10 & \$ 25 \\ >30 \text { minutes } & \$ 25 & \$ 50\end{array}$

\section{Oz Child}

Information Service

Please send a sample copy of Nexus and list of journals indexed

Name

Organisation

Address

Tel

Fax

RETURN TO: Oz Child Information Service

PO Box 1310, South Melbourne, Vic 3205

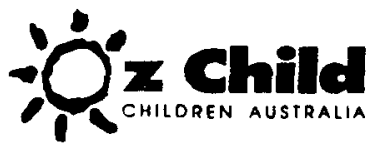




\section{Oz Child}

Information Service

The $\mathrm{Oz}$ Child Information Service (formerly NCBA Information Service) is a comprehensive, efficient and personalised service designed specifically to meet the information needs of human service professionals, researchers and managers in the field of child and family welfare. It provides up-to-date information, which is targeted, in-depth and easily accessible.

The Service has been operating since 1983, and has built up a valuable and significant collection and a solid reputation for the provision of an efficient and speedy response to the needs of its clients.

In addition to the approximately 180 workers within $\mathrm{Oz}$ Child, the Information Service also provides for the information needs of over one hundred external subscribers, agencies and individuals, located throughout Australia. The Service is specifically designed to assist workers and students in remote areas.

The key aim of the $\mathrm{Oz}$ Child Information Service is to provide access to current and useful information, as quickly and simply as possible, to anyone working with children and families or studying in this area.

\section{The Collection}

- Journals - there are approximately 120 journal subscriptions, from Australia and overseas, and since the service began, the abstracts of all relevant articles have been added to the Service's database, thus building a very strong information resource. The journal collection includes some material which is held nowhere else in Victoria, and in a few cases, in Australia. Back issues of all journals acquired by the Service are retained and their contents accessible via the database.

- Books - this is a very targeted collection of 5000 books which provides a solid complement to the journals. All books are available for loan.

- Videos - a wide range of subject areas are included in this collection of around 250 videos. All are available for loan.

The subject areas covered in all parts of the collection include the following:

- chila abuse/protection .

- child development

- early childhood

child/family legal issues

- adoption/fostering/substitute care

- domestic violence

- child/adolescent psychology

- child rearing and parenting

- family relationships

- family counselling/psychotherapy

- social work/management

- child health/disabilities

\section{The Services}

Information Service subscribers are located throughout Australia, some as far away as Western Australia and far north Queensland. Therefore, the services are provided almost entirely by telephone, mail and fax.

NEXUS is the Information Service's principal vehicle for the dissemination of information. It is a monthly publication which contains abstracts, created by the Information Service staff, of over 200 articles drawn from the current issues of journals from Australia and overseas. These abstracts are grouped under broad subject categories, and each has a number of keywords attached so that readers can quickly ascertain which articles may be relevant to their work or study. Photocopies of the full text of the selected articles can then be requested.

Books and Videos recently added to the collection are listed in Nexus, or special subject lists.

Database searches - can be requested by subscribers who want information on specific topics. A search is then performed on the total database which includes, as well as all books and videos, the cumulated resource of journal articles indexed for Nexus over many years. For example, a subscriber may request material on the effects of divorce on children - a database search would be conducted and a printout of the abstracts of all relevant material held in the collection would be produced. As with Nexus, the requestor can then ask for the full text of the articles, or borrow the books/videos which best meet his/her needs. 
